\title{
Experimental study of anaerobic digestion of dog waste
}

\author{
Okoroigwe, E. C.*, Ibeto, C. N. and Ezema, C. G. \\ National Centre for Energy Research and Development, University of Nigeria, Nsukka, Enugu State, Nigeria.
}

Received 07 October, 2013; Accepted 10 March, 2014

\begin{abstract}
Bioconversion of dog waste (dung) to energy as one of the ways for proper disposal of the waste was carried out through anaerobic digestion for biogas production. The 59-day experiment was performed within the slurry temperature range of 28 and $44^{\circ} \mathrm{C}$ using a $50 \mathrm{~L}$ metallic biodigester. Prior to charging the digesters, physico-chemical properties and microbial content of the waste were determined using standard methods. The results show that a cumulative gas production of $200 \mathrm{~L}$ was generated by $7 \mathrm{~kg}$ of the waste at the end of the test period while the microbial load decreased from $8.2 \times 10^{14}$ at the beginning of the test to $4.2 \times 10^{8}$ at the end of the retention time. Five microorganisms were identified at the beginning of the charging period, four were identified at the $20^{\text {th }}$ day when the gas began to burn due to methane production while only one microorganism was identified at end of the test. Even though it has longer retention period than most common animal wastes used for biogas production, its gas production rate is low. However, pathogen reduction through anaerobic digestion justifies its conversion to energy by this method.
\end{abstract}

Key words: Dog Waste, biogas, anaerobic digestion, renewable energy, biodigesters, microbial count.

\section{INTRODUCTION}

Proper waste management is an issue in developing countries. Diseases and sicknesses are associated with improper waste handling and disposal. One of the ways of preserving the environment which is being affected by global warning due to heavy consumption of fossil fuels is by use of alternative renewable energy fuels. By this, ground water contamination, diseases and sicknesses as well as air pollution are abated.

Biomass technology has become one of the sources of renewable energy fuels for the present and future energy use that will help reduce the level of environmental pollution resulting from use of fossil fuels and improper waste disposal. It is widely used as source of biomass energy for cooking, heating and electricity generation for lighting and running of internal combustion (IC) engines.

Biomass is accumulation of solar energy on earth in the form of plant and animal materials. Dog waste (excreta) is easily found littering the environment in developing countries due to poor handling and ignorance of its usefulness in energy production. Dog rearing is common among individuals and organizations as pet and for security purposes.

Bacteria and pathogens are associated with dog wastes (Beck, 1979) which are harmful to human health (Unruh et al., 1973). Of greatest concern here are parasitic worms, round worms, hookworms and tape worms (Prociv and Croese, 1990).

Composting is discouraged as a method of disposal of 


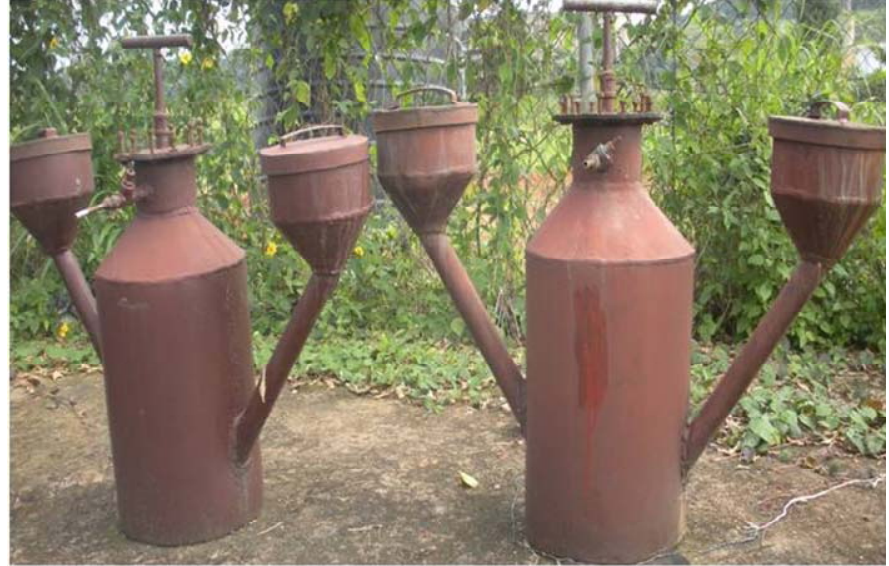

Figure 1. Biodigester prototype used in the experiment.

dog waste due to its pathogen content. It contains bacteria and pathogens that are harmful to humans. Like other animal manures, dog manure has high nitrogen content which increases its carbon to nitrogen ratio hence affecting the decomposition process (Taylor, 2004). Rather than allowing dog dung waste away, its energy potential is being explored. Animal waste is being screened to see how it might be reused in a bid to making the environment clean. Usually, if dog waste is not tossed out, it is left where it falls and dissolves into the ground where it flows untreated into the water table. Another common method of its disposal is by scooping into compost bin alongside the yard waste which can be regarded as poor method of disposal due to its susceptibility to human disease.

In this work it is proposed that one of the ways to get rid of the menace of dog dung is by anaerobic digestion for medium energy fuel production. Anaerobic digestion is the microbial decomposition of biomass in the absence of oxygen. The major product of this bacterial activity is the release of biogas, a combustible gas that is rich in methane and contains carbon dioxide, water and hydrogen sulphide in trace quantity. Anaerobic digestion of different animal wastes has been carried out by many scholars. Abubakar and Ismail (2012) have carried out an investigation on biogas production potential of cow dung using a laboratory scale $10 \mathrm{~L}$ bioreactor. It was found that cow dung stands a promising feedstock for biogas production even at a laboratory scale. Three wastes types comprising cow dung, cowpea and cassava peels have also been subjected to anaerobic digestion (AD) investigation by Ukpai and Nnabuchi (2012). In their work cowpea produced highest percentage of methane followed by cow dung while the cassava peels produced the least. On cumulative scale, cow dung produced the highest cumulative biogas yield of 124.3 L/total mass of slurry. At domestic level, $11 \mathrm{~m}^{3}$ biodigester has been operated at National centre for Energy Research and Development, University of Nigeria Nsukka using cow dung as feedstock (Eze et al., 2011). At full capacity, the biogas generated from cow dung using this digester is capable of producing energy required for up to $6 \mathrm{~h}$ of household continuous cooking. In Nepal, Singh et al. (2008) have demonstrated the use of poultry waste in biogas production. It was found that poultry droppings could provide additional energy required for the farm operation if anaerobic digestion is incorporated in the management of the wastes. Biogas generation from animal wastes is not limited to domestic or farm animals. Atanu et al. (2010) carried out laboratory experiment on biogas generation from $A D$ of elephant droppings. It was found that this waste can produce biogas containing 48 to $60 \%$ methane even though biogas generation did not start until after 12 days of fermentation.

A survey of scholarly articles show several works done on biogas generation using plant, animal and industrial wastes with little or no information on use of dog wastes for energy production. In the review of current advances in biogas production, provided by Demirel et al. (2010), dog waste is not mentioned as one of the wastes that could generate energy. Among all the animal wastes used so far for biogas production at both laboratory and field experiments, AD of dog waste is scarcely reported. This may be partly because of the quantity of the waste or partly because of its susceptibility to pathogens. Therefore it becomes important that biogas production potential of this waste be investigated with a view to advising for its proper disposal. Anaerobic digestion of animal wastes has been found to have a long time benefit. In some cases Anaerobic digestion processes have often been applied for biological stabilization of solid and liquid wastes (Demirel et al., 2010). Similarly, it has been found that the slurry (effluent) can be used in crop production as biofertilizer which has better nutrient quality than the raw waste (Okoroigwe, 2007; Okoroigwe et al., 2008). The aim of this investigation is to determine the biogas production potential of dog waste. The work will understudy the bacterial count of the digested effluent with a view to advising for its proper disposal.

\section{MATERIALS AND METHODS}

In this study, the dog waste (dung) used was collected from the dog unit of University of Nigeria, Nsukka security post and Department of Veterinary Medicine while the anaerobic digestion experiment was carried out at the National Centre for Energy Research and Development, (NCERD), University of Nigeria Nsukka. Prior to biodigestion process, proximate analysis of the waste was carried out using standard methods to determine the moisture and ash content. Physicochemical properties such as $\mathrm{pH}$, temperature, crude fibre, protein, fat etc were also determined prior and during the biodigestion period. The action of microorganisms in the decomposition process of the substrate is very important to determine the progress of biogas production. Hence, the microbial load of the substrate was determined at three different periods during the biodigestion process. This was determined using the surface viable count method outlined by Okore (2004). After determination of preliminary parameters of the substrate, the $A D$ proceeded with the charging of the $50 \mathrm{~L}$ biodigester (Figure 1) with 
Table 1. Result of proximate analysis.

\begin{tabular}{lc}
\hline Parameter & $\%$ \\
\hline Moisture & 74.8 \\
Ash & 1.50 \\
Protein & 2.19 \\
Fat & 0.15 \\
Fibre & 0.55 \\
Total solids & 25.2 \\
Volatile solids & 20.5 \\
Potassium & 1.50 \\
Calcium & 0.06 \\
Magnesium & 0.32 \\
Phosphorus (mg/100 g) & 0.48 \\
Carbon & 2.98 \\
Nitrogen & 0.175 \\
C:N ratio & 17.0 \\
Onset of flammability & $20^{\text {th }}$ day \\
\hline
\end{tabular}

$7 \mathrm{~kg}$ of dog dung mixed in $21 \mathrm{~kg}$ of water. The set up was made airtight to ensure anaerobic condition and kept in an open space at the biomass digestion ground of NCERD. This was to ensure that the set up was operated at the normal prevailing environmental conditions of temperature and pressure. The 59 day experiment lasted from December 2008 to January 2009.

Biogas generated was measured daily at specific time of the day to ensure $24 \mathrm{~h}$ gas production period. The volume of gas in liters was measured by downward displacement of water in a trough calibrated in $0.5 \mathrm{~L}$ scale.

The gas production rate was calculated according to the relation:

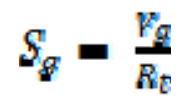

Where, $S_{g}=$ gas production $\left(\right.$ Lday $\left.^{-1}\right) ; V_{g}=$ cumulative gas production $(\mathrm{L})$, and $\mathrm{R}_{\mathrm{t}}=$ retention time (days)

\section{RESULTS AND DISCUSSION}

\section{Physico-chemical parameters}

The physical and chemical parameters of the sample as determined through the analysis above are presented in Table 1.

\section{C/N ratio}

Among factors that affect biogas yield from AD of wastes are $\mathrm{pH}$, Hydraulic Retention Time and $\mathrm{C} / \mathrm{N}$ ratio (Oparaku et al., 2013; Yadvika et al., 2004). According to Wang et al. (2012), C/N ratio is an important indicator for controlling biological treatment systems. High $\mathrm{C} / \mathrm{N}$ ratio indicates rapid nitrogen consumption by methanogens and leads to lower gas production while low $\mathrm{C} / \mathrm{N}$ ratio results in ammonia accumulation and an increase in $\mathrm{pH}$ values, which is toxic to methanogenic bacteria (Zhang et al., 2013). Usually, during anaerobic digestion, microorganisms utilize carbon 25 to 30 times faster than nitrogen (Yadvika et al., 2004). To meet this requirement, microbes need a 20 to $30: 1$ ratio of $C$ to $N$ ). The characterization result of the dog waste sample shows that it contains a $\mathrm{CN}$ ratio of 17 . This is small compared to the recommended ratio above. This could be responsible for the low gas production within the first 20 days of digestion (Figure 2). This is also responsible for the acidic nature of the slurry during the initial days (Figure 3).

\section{Flammability/methane content}

Flammability (evidence of methane content) started at the $20^{\text {th }}$ day which presumes that ammonia production due to low $\mathrm{CN}$ ratio might be predominant at early digestion days. This delay period was also obtained by Ofoefule and Uzodimma (2009) in the blend of cassava peels waste with pig dung in anaerobic digestion process. The explanation is also based on large ammonia production from cassava peels digestion.

\section{Effect of volatile solids and total solids (VS and TS)}

The result also shows that the waste has a volatile solid concentration of $20.5 \%$ and total solid concentration of $25.2 \%$ in the dung (Table 1). This shows the amount of the dung convertible to gaseous element and providing nutrients to the microorganisms for their function. The low VS contributed, along other parameters, to the low gas yield recorded in the first 20 days since the microbes could not breakdown the substrate as easily as possible. Gas yield increased from the $25^{\text {th }}$ day when there was a balance between the TS consumption and VS conversion to gas. The $25.2 \%$ TS and $74.2 \%$ moisture content of the dog waste are close to 20 and $80 \%$ respectively for human excreta due to the nature of diet dogs feed on.

\section{Biogas yield}

The biogas yield profile of the substrate (Figure 2) is typical of biogas production profile from anaerobic digestion of animal wastes. The profile is characterized by fluctuation in biogas production over time due to many factors which include complex microbial activities. The processes of $A D$ are complex chemical reactions between the microorganisms and the substrates which are affected by a number of factors as indicated above and the prevailing climatic and environmental factors. Temperature affects the reaction resulting in changes in biogas yield. The result of the daily gas yield of the dog waste is shown in Figure 2 while the cumulative biogas 


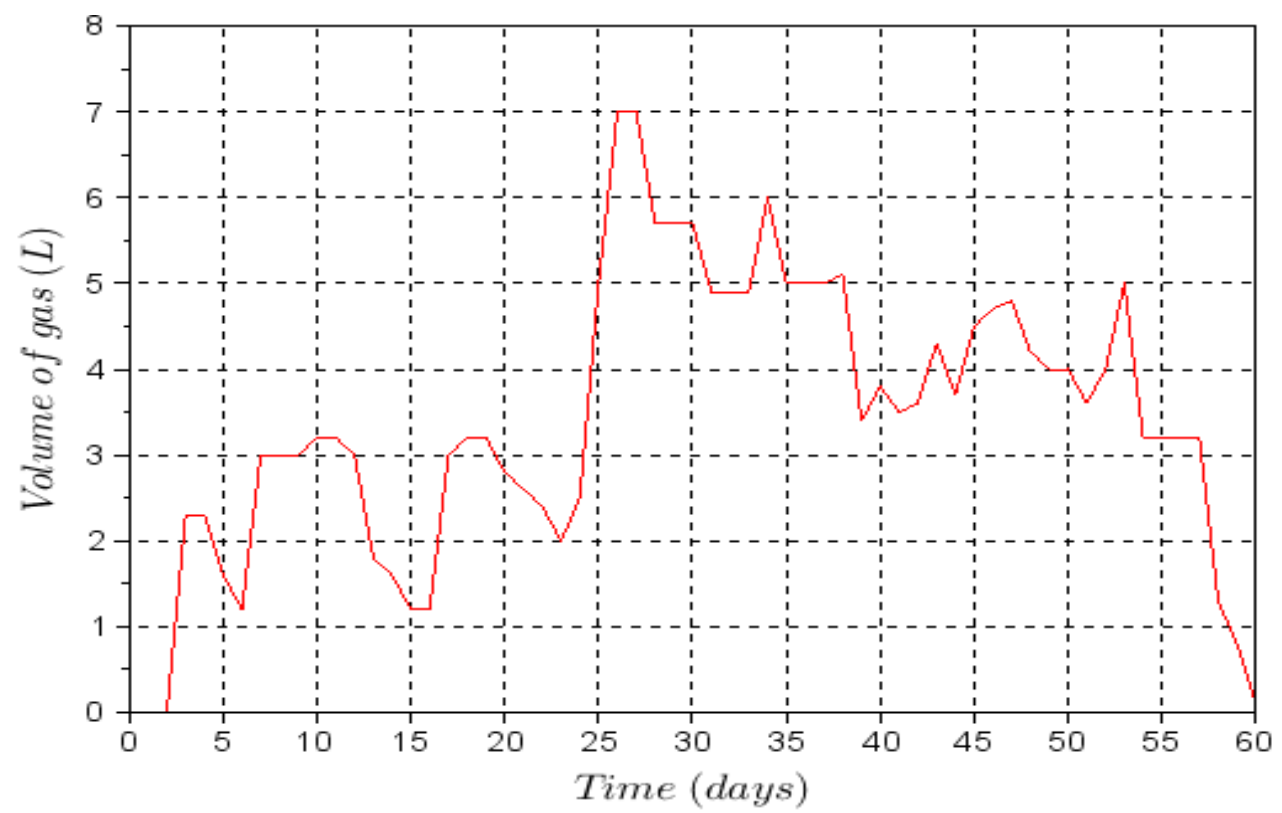

Figure 2. Daily biogas production from the dog waste.* is converted by authors from the original source.

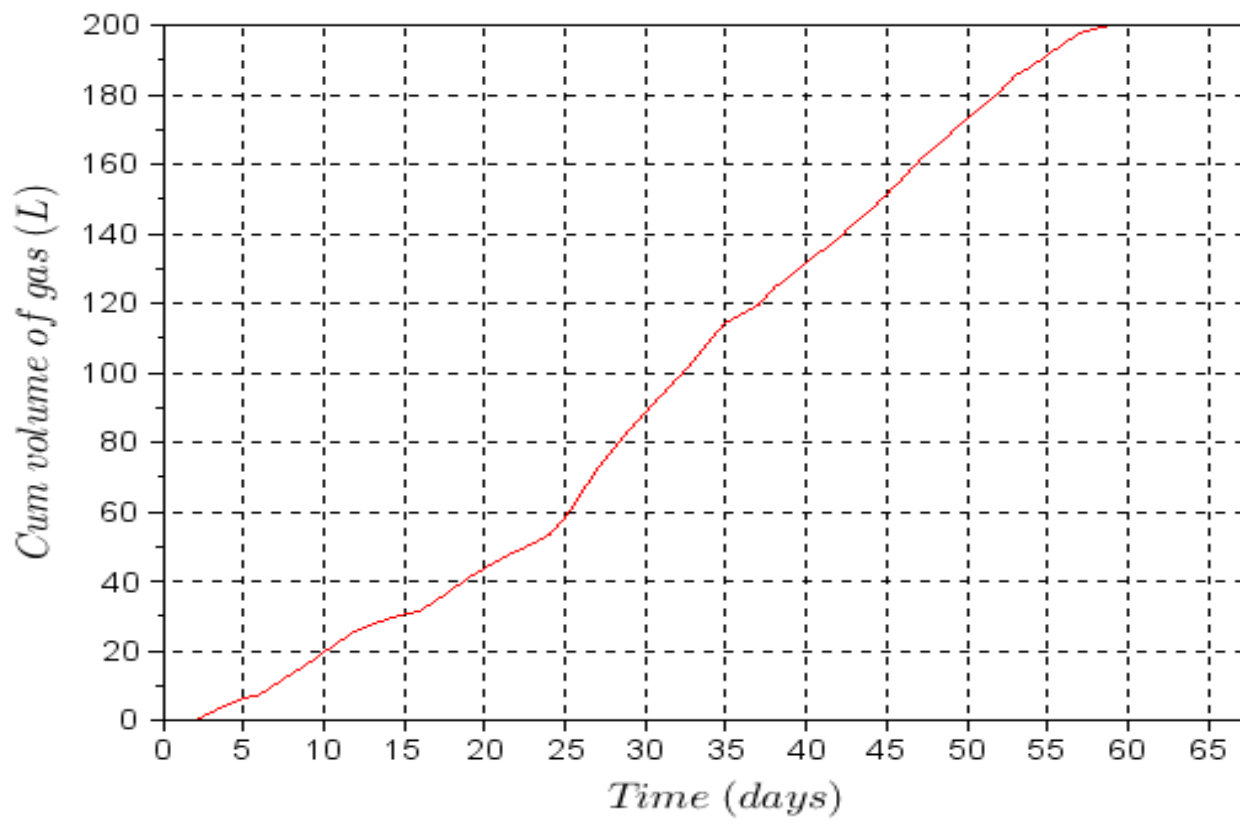

Figure 3. Cumulative biogas production of the dog waste.

production over the entire biodigestion period is shown in Figure 3 . The gas production rate is calculated as 0.07 L/day using Equation (1). On unit mass of substrate, the gas production specific volume yield (SVY) is $28.57 \mathrm{~L} / \mathrm{kg}$, or $0.029 \mathrm{~m}^{3} / \mathrm{kg}$. This value is similar to $0.028 \mathrm{~m}^{*} / \mathrm{kg}$ reported by Balasubramaniyam et al. (2008) for human excreta. This could be because both animal wastes type have similar physico-chemical properties. The dog's biogas SVY is less that $0.3,0.5$ and $0.5 \mathrm{~m}^{3} / \mathrm{kg}$ reported by llaboya et al. (2010) for Cattle dung, Pig dung and Poultry droppings respectively. Since human waste has been used for biogas production, dog waste can be used also. An advantage of using dog dung for biogas production is on its long retention time as gas production 


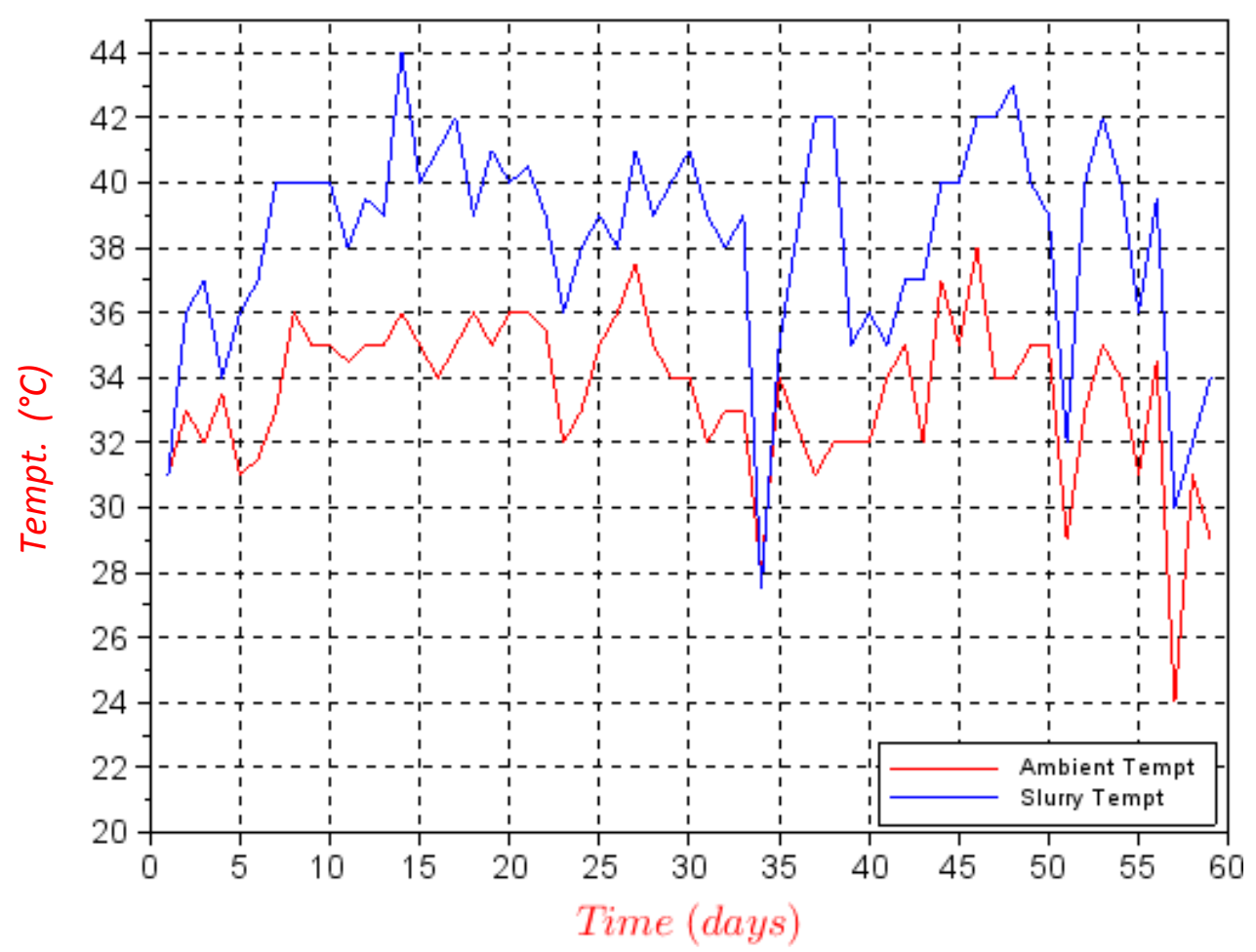

Figure 4. Temperature variation during the biodigestion period.

continued up to $59^{\text {th }}$ day. The quantity of dog waste product is a limitation in using this for large biogas production.

For the 59-day testing of the wastes, a total of $200 \mathrm{~L}$ of gas were collected.

\section{Temperature effect}

Figure 4 shows the temperature variation during the test period. The slurry temperature was between 28 and $44^{\circ} \mathrm{C}$ which is the mesophillic temperature regime. There was no external influence of the slurry temperature as this was only affected by the activities of microorganisms. The external temperature (ambient) was only influenced by natural weather condition. The period was during the harmatan wind characterized by dryness and cold wind across Sahara. The highest ambient temperature was $38^{\circ} \mathrm{C}$ while the lowest was $24^{\circ} \mathrm{C}$. This condition is favourable for biogas production during $A D$ of animal wastes unlike adverse cold witnessed during winter in temperate climate when the temperature assumes negative values.

\section{$\mathrm{pH}$ variation}

The $\mathrm{pH}$ of the slurry ranged from 6.36 to 7.78 as shown in Figure 5. The microorganisms that are involved in biodigestion processes are usually affected by the acidity of the medium. The activities of these acitogens and methanogens result in the variation of $\mathrm{pH}$ of the medium and subsequently affect biogas production. Optimum biogas production is usually obtained within the $\mathrm{pH}$ range of 6.5 to 7.5. Maximum gas production was obtained between the 25 th and the $35^{\text {th }}$ day (Figure 2) when the $\mathrm{pH}$ was near neutral (Figure 5).

\section{Microbial load}

Table 2 presents the type and number of microorganisms in the waste at major times of the analysis. It shows that the waste had higher microorganism content at the beginning which was a combination of aerobic and anaerobic organisms. At flaming period the organisms (Butyrivibrio sp.) were no longer present which was responsible for the decrease in the microbial count (TVC) of the identified organisms. These were responsible for aerobic activities that utilized initial oxygen trapped in the system at commencement of fermentation. When methane began to build up Clostridium sp., Ruminococcus sp., Acetivibrio sp. and Eubacteriumcellulosolvens were predominant. It could be affirmed that methane production could be hindered as long as Butrivibrio sp. remains in the system. Identification of the quantity of each microorganism can explain better the role of each organism in production of flammable gas. 


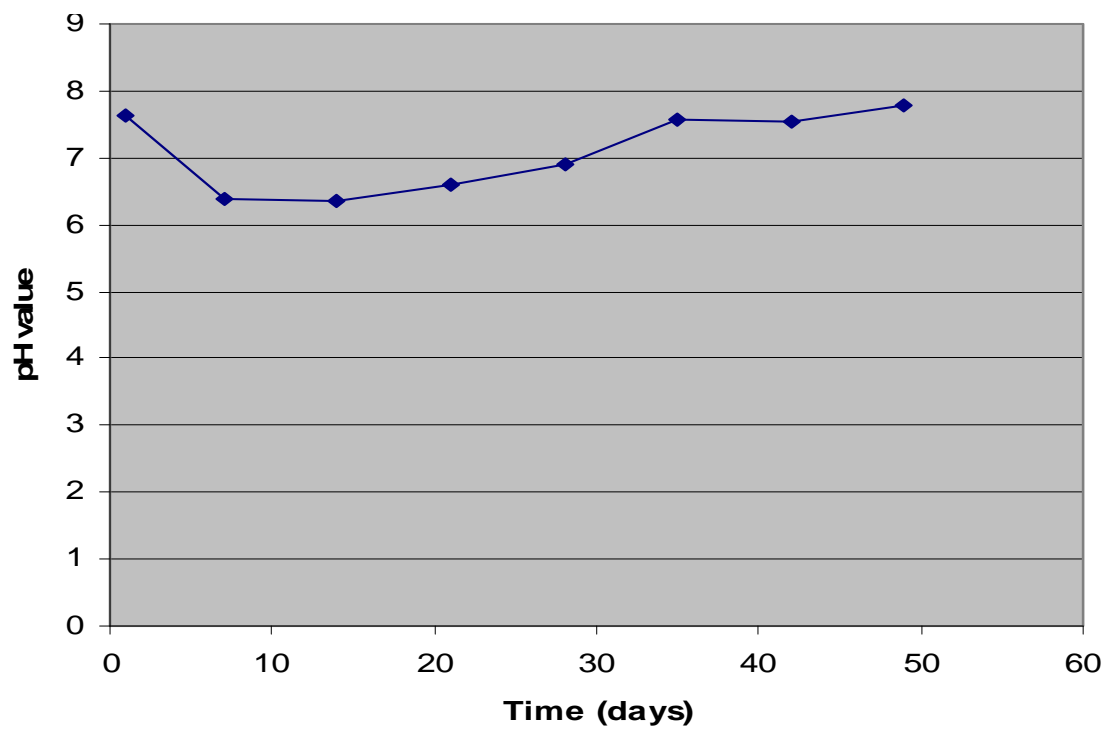

Figure 5. $\mathrm{pH}$ variation of the waste.

Table 2. Organisms/microbial species isolated and TVC at various stages of the anaerobic digestion of the dog feaces.

\begin{tabular}{llll}
\hline Organisms & At charging of waste & At flammability & At the end of gas production \\
\hline & Butyrivibrio sp., & Clostridium $\mathrm{sp} .$, & \\
& Clostridium sp., & Ruminococcus sp., & Clostridium sp. \\
Bacteria type & Ruminococcus sp., & Acetivibrio sp., & \\
& Acetivibrio sp., & Eubacterium- cellulosolvens & \\
& Eubacterium-Cellulosolvens. & & $4.2 \times 10^{8}$ \\
& & & \\
TVC & $8.2 \times 10^{14}$ & $7.6 \times 10^{11}$ & \\
\hline
\end{tabular}

This further reveals the total disappearance of all the organisms at the end of the production stage leaving only the Clostridium sp. This conforms to the conclusion of Ofoefule et al. (2010) that AD does not completely eliminate microorganism in animal wastes. This probably implies that these bacteria were not involved in gas production or that the environment might not be conducive for their activity even though they accounted for 420 million of the identified organisms (Table 2). Decrease in microbial load over the period of biodigestion is a common phenomenon in microbial reactions. This has been observed by McGarvey et al. (2007) and Ofoefule et al. (2010).

\section{Conclusion}

Different biomass materials have different biogas generation potential. Whereas many have been tested to have high biogas viability, dog waste has low biogas production potential. From the results obtained, it can be seen that dog waste has biogas generation potentials even though the production rate is very slow and with high retention time. Although gas yield was low, it can be used as innoculum for increasing the retention time of other biomass since it has high retention time. It is not however advisable to depend on dog waste alone for biogas production mainly due to the quantity of biomass is usually small and its biogas has long time to flame. Anaerobic digestion is a better option to composting in terms of pathogen handling and control.

\section{Conflict of Interests}

The author(s) have not declared any conflict of interests.

\section{REFERENCES}

Abubakar BSUI, Ismail N (2012). Anaerobic Digestion of Cow Dung for Biogas Production. ARPN J. Eng. Appl. Sc. 7(2):169-172.

Atanu OS, Asere AA, Philips TK (2010). Biogas Generation From Anaerobic Digestion of Elephant Droppings. Nig. J. Solar Energy 21:145-148. 
Balasubramaniyam U, Llionel SZ, Niccoló M, Buysman V (2008). Biogas production in climates with long cold winters. Documentation Prepared by Wageningen University, the Netherlands for Women in Europe for a Common Future, WECF The Netherlands, pp. 1-68.

Beck AM (1979). The Impact of the Canine Clean-up Law: Both Dogs and People Profit Environment. Sci. Pol. Sustain. Dev. 21(8):28-31. http://dx.doi.org/10.1080/00139157.1979.9931200

Demirel B, Scherer P, Orhan Y, Turgut TO (2010). Production of Methane and Hydrogen from Biomass through Conventional and High-Rate Anaerobic Digestion Processes. Crit. Rev. Environ. Sci. Tech. 40:116-146. http://dx.doi.org/10.1080/10643380802013415

Eze IS, Ofoefule AU, Uzidinma EOU, Okoroigwe EC, Oparaku NF, Eze JI, Oparaku OU (2011). Characterization and Performance Evaluation of $11 \mathrm{~m}^{3}$ Biogas Plant Constructed at National Centre for Energy Research and Development, University of Nigeria, Nsukka. Cont. J. Renew. Energy 2(1):1-6.

Ilaboya IR, Asekhame FF, Ezugwu MO, Erameh AA, Omofuma FE (2010). Studies on Biogas Generation from Agricultural Waste; Analysis of the Effects of Alkaline on Gas Generation. World App. Sc. J. 9(5):537-545.

McGarvey JA, William GM, Ruihong Z, Yanguo M, Frank M (2007) Bacterial Population Dynamics in Dairy Waste during Aerobic and Anaerobic Treatment and Subsequent Storage. Appl. Environ. Microbiol. 73(1):193-202. http://dx.doi.org/10.1128/AEM.01422-06; PMid:17085701 PMCid:PMC1797099

Ofoefule AU, Uzodinma EO (2009). Biogas production from blends of cassava (Manihot utilissima) peels with some animal wastes. Int. J. Phys. Sci. 4(7):398-402.

Ofoefule AU, Uzodinma EO, Anyanwu CN (2010). Studies on the Effect of Anaerobic Digestion on on the Microbial Flora of Animal Wastes 2: Digestion and Modeling of Process Parameters. Trends Appl. Sci. Res. 5(I):39-47.

Okore VC (2004): Surface Viable Count Method. A standard laboratory technique in Pharmaceutics and Pharmaceutical Microbiology. 2nd Edn. El'Demark Publishers, pp. 24-26.

Okoroigwe EC. (2007). Application of Biomass Technology in Sustainable Agriculture. Trends Appl. Sci. Res. 2(6):549-553. http://dx.doi.org/10.3923/tasr.2007.549.553

Okoroigwe EC, Eze JI, Oparaku OU (2008). Field Comparison of Biofertilizer and Chemical Fertilizer Application on Maize Production. Nig. J. Solar Energy 19(1):55-57.

Oparaku NF, Ofomatah AC, Okoroigwe EC (2013). Biodigestion of Cassava Peels Blended with Pig Dung for Methane Generation. Afr. J. Biotechnol. 12(40):5956-5961.
Prociv P, Croese J (1990). Human Eosinophilic Enteritis Caused by Dog Hookworm Ancylostoma caninum. Lancet 335(8701):1299-1302. http://dx.doi.org/10.1016/0140-6736(90)91186-E

Singh R, Amrit BK, Jagan NS (2008). Production of Biogas from Poultry Waste. Int. J. Renew. Energy 3(1):11-20.

Taylor L (2004). Poop, Scoop and Compost: Proposal to Explore the Feasibility of Composting Dog Waste in Public Parks.

Ukpai PA, Nnabuchi MN (2012). Comparative study of biogas production from cow dung, cow pea and cassava peeling using 45 litres biogas digester. Adv. Appl. Sci. Res. 3(3):1864-1869.

Unruh DHA, King JE, Eaton RDP, Allen JR (1973). Parasites of Dogs from Indian Settlements in Northwestern Canada: A Survey with Public Health Implications. Can. J. Comp. Med. 37:25-32. PMid:4265550 PMCid:PMC1319720

Wang X, Yang G, Feng Y, Ren G, Han X (2012). Optimizing feeding composition and carbon-nitrogen ratios for improved methane yield during anaerobic co-digestion of dairy, chicken manure and wheat straw. Bioresour. 120:78-83. http://dx.doi.org/10.1016/j.biortech.2012.06.058; PMid:22784956

Yadvika S, Sreekrishnan TR, Sangeeta K, Vineet R (2004). Enhancement of biogas production from solid substrates using different techniques - A review. Bioresour. Technol. 95 (1):1-10. http://dx.doi.org/10.1016/j.biortech.2004.02.010; PMid:15207286

Zhang T1, Liu L, Song Z, Ren G, Feng Y, Han X, Yang G (2013). Biogas Production by Co-digestion of Goat Manure with Three Crop Residues. PLOSONE 8(6):e66845. 